\title{
Antinociceptive activity of methanolic extract of Muntingia calabura leaves: further elucidation of the possible mechanisms
}

Zainul Amiruddin Zakaria ${ }^{1,3^{*}}$, Mohd Hijaz Mohd Sani ${ }^{1}$, Manraj Singh Cheema', Arifah Abdul Kader ${ }^{2}$, Teh Lay Kek ${ }^{3}$ and Mohd Zaki Salleh ${ }^{3}$

\begin{abstract}
Background: Muntingia calabura (Elaecoparceae) is a medicinal plant traditionally used, particularly, by the Peruvian people to alleviate headache and cold, pain associated with gastric ulcers or to reduce the prostate gland swelling. Following the recent establishment of antinociceptive activity of $M$. calabura leaf, the present study was performed to further elucidate on the possible mechanisms of antinociception involved.

Methods: The methanol extract of M. calabura (MEMC) was prepared in the doses of 100, 250 and $500 \mathrm{mg} / \mathrm{kg}$. The role of bradykinin, protein kinase C, pottasium channels, and various opioid and non-opioid receptors in modulating the extract's antinociceptive activity was determined using several antinociceptive assays. Results are presented as Mean \pm standard error of mean (SEM). The one-way ANOVA test with Dunnett's multiple comparison was used to analyze and compare the data, with $P<0.05$ as the limit of significance.

Results: The MEMC, at all doses, demonstrated a significant $(p<0.05)$ dose-dependent antinociceptive activity in both the bradykinin- and phorbol 12-myristate 13-acetate (PMA)-induced nociception. Pretreatment of the $500 \mathrm{mg} / \mathrm{kg}$ MEMC with $10 \mathrm{mg} / \mathrm{kg}$ glibenclamide (an ATP-sensitive $\mathrm{K}^{+}$channel inhibitor), the antagonist of $\mu$-, $\delta$ - and $\mathrm{k}$-opioid receptors (namely $10 \mathrm{mg} / \mathrm{kg} \beta$-funaltrexamine, $1 \mathrm{mg} / \mathrm{kg}$ naltrindole and $1 \mathrm{mg} / \mathrm{kg}$ nor-binaltorphimine), and the non-opioid receptor antagonists (namely $3 \mathrm{mg} / \mathrm{kg}$ caffeine (a non-selective adenosinergic receptor antagonist), $0.15 \mathrm{mg} / \mathrm{kg}$ yohimbine (an $\mathrm{a}_{2}$-noradrenergic antagonist), and $1 \mathrm{mg} / \mathrm{kg}$ pindolol (a $\beta$-adrenoceptor antagonist)) significantly $(p<0.05)$ reversed the MEMC antinociception. However, $10 \mathrm{mg} / \mathrm{kg}$ atropine (a non-selective cholinergic receptor antagonist), $0.15 \mathrm{mg} / \mathrm{kg}$ prazosin (an $\mathrm{a}_{1}$-noradrenergic antagonist) and $20 \mathrm{mg} / \mathrm{kg}$ haloperidol (a non-selective dopaminergic antagonist) did not affect the extract's antinociception. The phytochemicals screening revealed the presence of saponins, flavonoids, tannins and triterpenes while the HPLC analysis showed the presence of flavonoid-based compounds.

Conclusions: The antinociceptive activity of MEMC involved activation of the non-selective opioid (particularly the $\mu$-, $\delta$ - and k-opioid) and non-opioid (particularly adenosinergic, $a_{2}$-noradrenergic, and $\beta$-adrenergic) receptors, modulation of the ATP-sensitive $\mathrm{K}^{+}$channel, and inhibition of bradikinin and protein kinase $\mathrm{C}$ actions. The discrepancies in MEMC antinociception could be due to the presence of various phytochemicals.
\end{abstract}

Keywords: Muntingia calabura, Elaecocarpaceae, Methanol extract, Antinociceptive activity, Mechanisms of action

\footnotetext{
* Correspondence: dr_zaz@yahoo.com

'Department of Biomedical Sciences, Faculty of Medicine and Health

Sciences, Universiti Putra Malaysia, 43400 Serdang, Selangor, Malaysia

${ }^{3}$ Integrative Pharmacogenomics Institute (iPROMISE), Level 7, FF3, Universiti

Teknologi MARA, Puncak Alam Campus, 42300 Puncak Alam, Selangor,

Malaysia

Full list of author information is available at the end of the article
} 


\section{Background}

Pain, as defined by the International Association for the Study of Pain (IASP), is "an unpleasant sensory or emotional experience associated with actual or potential tissue damage, or described in terms of such damage." The definition empathizes pain as a complex multidimensional sensory-perceptual phenomenon that represents a unique subjective experience for each individual [1]. Pain is usually considered as a warning signal of actual or perceived tissue damage. In other word, pain which is produced by an external stimulus can therefore elicit reflex and conscious avoidance reaction to protect the body from potential harms. Nevertheless, pain can occur in the absence of tissue damage, even though the experience may be described as if the damage has occurred [2].

Receptors have their respective field or defined area from which they receive information. These nerve endings respond to noxious stimuli and transmit the information via afferent or sensory fibers to the CNS [3]. The dorsal horn is the gray matter in the posterior aspect of the spinal cord which is highly involved in pain integration, modification and relay. Pain impulses exit dorsal horn and ascend the spinal cord to the higher processing centers of the brain. The predominant pathways for pain conduction are the spinothalamic tract which synapse in the thalamus, and the spinoreticulothalamic tract which synapses in the reticular formation. The distinction in function of these two paths is not known [4]. Through pharmacological manipulation, it is possible to alter pain by decreasing transmission of pain signals to the brain or by increasing the inhibitory signal from the CNS [5].

Focusing on natural products as an alternative to many medications has been a major interest among scientists nowadays. Natural products as referred to Holt and Chandra [6] are herbs, herbal concoctions, dietary supplements, traditional Chinese medicines or alternative medicines. Natural product research is guided by ethnopharmacological knowledge and has brought substantial contributions to drug innovation by providing novel chemical structures and/or mechanism of actions [7]. Muntingia calabura, the sole species in the genus Muntingia, has been widely used as a traditional medication in the Southeast Asia and tropical America [8,9] to treat headaches and gastric ulcer, and as an emmenogogue, antidyspeptic, antispasmodic, diaphoretic, tranquillizer and tonic $[8,10]$.

Scientifically, various medicinal properties have been reported, including anti-tumor $[8,11]$, antibacterial $[12,13]$, anti-inflammatory, antipyretic and antinociceptive [14,15], antiproliferative and antioxidant [16], antihypertensive [17] and antiulcer [18] activities. With regards to the antinociceptive mechanisms, several papers have reported on the involvement of various receptor systems (e.g. opioid, atropine, phenoxybenzamine, yohimbine, pindolol, haloperidol and bicuculline), L-arginine/nitric oxide/cyclic guanosine monophosphate pathway, vanilloid receptors and glutamatergic system in the modulation of antinociceptive activity of $M$. calabura extracts, namely the aqueous and chloroform extracts [19-22]. Moreover, it is suggested that the synergistic effect of the bioactive compounds, flavonoids, saponins, tannins and steroids, played an important role in the observed activities [16]. Recently, we have proved that the methanol extract of M. calabura (MEMC) leaves possesses good therapeutic effect in reducing nociceptive response [23] and further study by Mohd. Yusof et al. [24] leads to the isolation of 4 flavonoid-based antinociceptive-bearing bioactive compounds, of which one is a new compound called calaburone (8-hydroxy-6-methoxyflavone) and three were known compounds, namely 5-hydroxy-3,7,8-trimethoxyflavone, 3,7-dimethoxy-5-hydroflavone and 2,4'-dihydroxy-3'-methoxychalcone. In this study, we further evaluate the possible mechanisms involved in the antinociceptive activity of the MEMC.

\section{Methods \\ Plant collection}

The leaves of $M$. calabura, collected from its natural habitat in Shah Alam, Selangor, Malaysia, were reidentified by Mr. Shamsul Khamis from the Institute of Bioscience (IBS), Universiti Putra Malaysia (UPM), Serdang, Selangor, Malaysia. A voucher specimen (SK 964/04) has been deposited in the Herbarium of the Laboratory of Natural Products, IBS, UPM, Serdang, Selangor, Malaysia.

\section{Preparation of plant extract}

This procedure was carried out as described in detail by Zakaria et al. [19]. Briefly, $500 \mathrm{~g}$ of matured leaves that have been air-dried for 1-2 weeks at room temperature $\left(27 \pm 2^{\circ} \mathrm{C}\right)$ and grinded into powder were soaked in methanol in the ratio of 1:20 (w/v) for 72 hours. After that, the supernatant was filtered using steel filter, cotton, and Whatman no. 1 filter paper. The residue was subjected to the same procedures for another two times. The supernatant collected from each extraction was pooled together and then subjected to evaporation process using a rotary evaporator at $40^{\circ} \mathrm{C}$ under reduced pressure. The crude extract obtained was used to prepare the desired dose of treatment by dissolving them into 10\% DMSO.

\section{Drugs and chemicals}

The drugs apamin, charybdotoxin, tetraethylammonium chloride, atropine, haloperidol, pindolol, yohimbine, prazosin, phenylpherine, clonidine, caffeine, glibenclamide, $\beta$-funaltrexamine, naltrindole, nor-binaltorphimine, all purchased from Sigma Aldrich (U.S.A.) and bradykinin (Tocris Bioscience, U.K.), were prepared at the desired dose by dissolving them in distilled water $\left(\mathrm{dH}_{2} \mathrm{O}\right)$. Phorbol 12-myristate 13-acetate 
(Sigma Aldrich, USA) was dissolved in PBS solution. Acetic acid and dimethyl sulfoxide (DMSO) were purchased from Fisher Scientific (U.K.).

\section{Animals}

Male ICR mice (25-30 g; 5-7 weeks old) and male Sprague-dawley rats (150-180 g) obtained from the Veterinary Animal Unit, Faculty of Veterinary Medicine, Universiti Putra Malaysia (UPM), Malaysia, and kept under room temperature $\left(27 \pm 2^{\circ} \mathrm{C} ; 70-80 \%\right.$ humidity; $12 \mathrm{~h}$ light/darkness cycle) in the Animal Holding Unit (UPM), were supplied with food and water ad libitum up to the beginning of the experiments. The rats were, at all times, handled in accordance with current UPM guidelines for the care of laboratory animals and the ethical guidelines for investigations of experimental pain in conscious animals [25]. The study protocol of the present study was approved by the Animal House and Use Committee, Faculty of Medicine and Health Sciences, UPM (Ethical approval no.: UPM/FPSK/PADS/ BR-UUH/00404). All experiments were conducted between 09.00 and $16.00 \mathrm{~h}$ to minimize the effects of environmental changes.

\section{Phytochemical and HPLC analysis of MEMC Phytochemical screening of dried leaves and MEMC}

The phytochemical screening of dried leaves of $M$. Calabura and MEMC was performed according to the standard screening tests and conventional protocols as adopted by Zakaria et al. [16].

\section{HPLC analysis of MEMC}

The HPLC analysis of MEMC was performed according to method by Balan et al. [18] with slight modification. Briefly, $10 \mathrm{mg}$ of MEMC was dissolved in $1 \mathrm{ml}$ methanol and then filtered through the membrane filter (pore size $0.45 \mu \mathrm{m}$ ). A Waters Delta 600 with 600 Controller and Waters 2996 Photodiode Array (Milford, MA, USA) equipped with an autosampler, online degasser and column heater was used to analyze the filtered sample. Data was evaluated and processed using the installed Millenium 32 Software (Waters Product). The filtered samples were separated at $27^{\circ} \mathrm{C}$ on a minibore Phenomenex Luna $5 \mu \mathrm{m} \mathrm{C}_{18}$ column (dimensions $250 \times 4.60 \mathrm{~mm}$ ) \using a one-step linear gradient. The solvents were (A) $0.1 \%$ aqueous formic acid and (B) acetonitrile and the elution system was as follows: Initial conditions were $95 \% \mathrm{~A}$ and $5 \% \mathrm{~B}$ with a linear gradient reaching $25 \% \mathrm{~B}$ at $\mathrm{t}=12 \mathrm{~min}$. This was maintained for $8 \mathrm{~min}$ after which the programm decreased to $15 \% \mathrm{~B}$ at $\mathrm{t}=22 \mathrm{~min}$ and was maintained for another $8 \mathrm{~min}$. The programm then was returned to the initial solvent composition at $\mathrm{t}=35 \mathrm{~min}$. The flow rate used was $1.0 \mathrm{ml} / \mathrm{min}$ and the injection volume was $10 \mu \mathrm{l}$. The HPLC was monitored at 254 and $366 \mathrm{~nm}$.

\section{Antinociceptive assays}

\section{Involvement of protein kinase $C$}

The experiment was conducted based on the previously described method by Savegnago et al. [26]. A volume of $50 \mu \mathrm{l}$ of PMA (a protein kinase $\mathrm{C}$ activator) solution $(0.05 \mu \mathrm{g} / \mathrm{paw})$ was injected into the ventral surface of the right hind paw of the rat $60 \mathrm{~min}$ after the oral administration of vehicle, ASA (100 mg/kg) or MEMC (100, 250 and $500 \mathrm{mg} / \mathrm{kg}$ ). The animals were observed individually from 15-45 min following PMA injection and the amount of time the rat spent licking the injected paw was recorded using a chronometer.

\section{Bradykinin-induced nociception}

Based on the method previously described by Ferreira et al. [27], bradykinin $(10 \mathrm{nmol} / \mathrm{paw}$ in $50 \mu \mathrm{l})$ was injected into the plantar ventral surface of the right hind paw $60 \mathrm{~min}$ after the oral administration of vehicle, ASA $(100 \mathrm{mg} / \mathrm{kg})$ or MEMC (100, 250 and $500 \mathrm{mg} / \mathrm{kg})$. The induced-rat was observed individually for $10 \mathrm{~min}$, and the amount of time they spent licking the injected paw was recorded.

\section{Involvement of potassium channels}

To determine the contribution of $\mathrm{K}^{+}$channels in MEMCinduced antinociception a method previously described by Alves and Duarte [28] was used. Mice were pre-treated with glibenclamide (an ATP sensitive $\mathrm{K}^{+}$channel inhibitor; $10 \mathrm{mg} / \mathrm{kg}$, i.p.), apamin (an inhibitor of small conductance $\mathrm{Ca}^{2+}$-activated $\mathrm{K}^{+}$channels, $0.04 \mathrm{mg} / \mathrm{kg}$, i.p.), charybdotoxin (an inhibitor of large conductance $\mathrm{Ca}^{2+}$-activated $\mathrm{K}^{+}$channels, 0.02, i.p.) or tetraethylammonium chloride (a non-selective voltage dependant $\mathrm{K}^{+}$channel inhibitor, $4 \mathrm{mg} / \mathrm{kg}$, i.p.) $15 \mathrm{~min}$ before oral administration of either vehicle or MEMC (500 mg/kg). Sixty minutes later, pain was induced using $0.6 \%$ acetic acid. The number of writhing was recorded for $25 \mathrm{~min}, 5 \mathrm{~min}$ following acetic acid injection.

\section{Effect of various receptor antagonists on MEMC-induced antinociception}

The doses of drug administered to elucidate the possible involvement of the following receptor system was based on the method previously described by De Souza et al. [29], followed by pain induction using acetic acid-induced abdominal writhing test described by Mohd. Sani et al. [23]. Groups of animal were pre-treated with caffeine $(3 \mathrm{mg} / \mathrm{kg}$, i.p.), atropine (10 $\mathrm{mg} / \mathrm{kg}$, i.p.), haloperidol $(20 \mathrm{mg} / \mathrm{kg}$, i.p.), pindolol (1 mg/kg. i.p.), yohimbine $(0.15 \mathrm{mg} / \mathrm{kg}$, i.p), prazo$\sin (0.15 \mathrm{mg} / \mathrm{kg}$, i.p), phenylphrine $(10 \mathrm{mg} / \mathrm{kg}$, i.p.) or clonidine $(0.15 \mathrm{mg} / \mathrm{kg}$, i.p.) 15 minutes before the administration of MEMC (500 mg/kg, p.o). The pain was induced using $0.6 \%$ acetic acid 60 minutes after the administration of MEMC or vehicle. The number of writhing was counted 
cumulatively over the period of 25 minutes, 5 minutes following acetic acid injection.

\section{Analysis of opioid receptor subtypes}

Evaluation of opioid receptor subtype involvement was done using an abdominal constriction test which is similar to previously described methods [30,31]. The doses of the opioid antagonists and timing of administration were based on previous studies conducted by Choi et al. [30] and Reeta et al. [31]. The $\mu$ opioid antagonist, $\beta$-funaltraxamine ( $\beta$-FNA; $10 \mathrm{mg} / \mathrm{kg}$, i.p.), $\delta$ opioid receptor antagonist, naltrindole (NALT; $1 \mathrm{mg} / \mathrm{kg}$. i.p.) or $\mathrm{K}$ opioid receptor antagonist, nor-binaltorphimine (nor-BNI; $1 \mathrm{mg} /$ $\mathrm{kg}$, i.p.) were administered $90 \mathrm{~min}, 15 \mathrm{~min}$ and $30 \mathrm{~min}$ respectively, before oral administration of $500 \mathrm{mg} / \mathrm{kg}$ of MEMC. The nociceptive stimuli was injected 60 minutes after MEMC administration.

\section{Statiscal analysis}

The results are presented as Mean \pm standard error of mean (SEM). The one-way ANOVA test with Dunnett's multiple comparison was used to analyze and compare the data, with $P<0.05$ as the limit of significance.

\section{Result}

Phytochemical screening and HPLC analysis of MEMC

Table 1 showed the present of flavonoids, triterpenes, tannins, saponins and steroids in both the dried leaves and MEMC. There is, however, no alkaloids present based on the performed phytochemical screening. The HPLC profile of MEMC showed five major peaks at the wavelength of 254 and $366 \mathrm{~nm}$ (Figure 1A). The best isolation of the detected peaks (4 peaks) was observed at the wavelength of $366 \mathrm{~nm}$. The four major peaks appeared in the chromatogram at the $366 \mathrm{~nm}$ wavelength tested at retention times of 20.436, 21.26, 22.756 and $23.52 \mathrm{~min}$. Further analysis demonstrated that the five peaks showed $\lambda_{\max }$ values in the region of 216.6-278, 209.6-352.9, 224.8-364.2, 221.3-347 and 229.5-350.6 nm, respectively (Figure 1B).

\section{Evaluation of protein kinase $\mathrm{C}$ and bradykinin receptor in MEMC-induced antinociception}

Figure 2 shows that the oral administration of 100, 250 and $500 \mathrm{mg} / \mathrm{kg}$ MEMC produced significant $(\mathrm{p}<0.01$ and $\mathrm{p}<0.001$ ) inhibition of PMA-induced nociception in rat. Interestingly, the $500 \mathrm{mg} / \mathrm{kg}$ MEMC exerted antinociceptive activity which was of similar intensity to that of $100 \mathrm{mg} / \mathrm{kg}$ ASA indicated by the similar percentage of analgesia recorded (58.55\% and $55.36 \%$ respectively).

As seen in Figure 3, MEMC given orally exhibits significant $(\mathrm{p}<0.05)$ inhibition in a dose-dependant manner on the nociception caused by intra-plantar injection of bradykinin $(10 \mathrm{nmol} / \mathrm{paw})$ in rat. The maximal inhibition observed was $53.92 \%$ for the dose of $500 \mathrm{mg} / \mathrm{kg}$ MEMC. Similar inhibitory effect was observed for $100 \mathrm{mg} / \mathrm{kg}$ ASA.

\section{Involvement of potassium channels and, non-opioid and opioid receptors on MEMC-induced antinociception}

Figure 4 shows the involvement of potassium channels in the modulation of MEMC-induced antinociceptive activity. Pretreatment with glibenclamide $(10 \mathrm{mg} / \mathrm{kg}$, i.p.), apamin $(0.04 \mathrm{mg} / \mathrm{kg}$, i.p.), charybdotoxin $(0.02$, i.p.) and tetraethylammonium chloride $(4 \mathrm{mg} / \mathrm{kg}$, i.p.), significantly $(\mathrm{p}<0.01)$ reversed the antinociceptive activity of MEMC $(500 \mathrm{mg} / \mathrm{kg})$ when assessed using acetic acid-induced abdominal writhing test.

The antinociceptive activity of MEMC was also significantly $(\mathrm{p}<0.05)$ reversed following intraperitoneal

Table 1 Comparison on the phytochemical constituents between the leaves of $M$. calabura and MEMC

\begin{tabular}{|c|c|c|c|}
\hline Phytochemical constituent & Sample & Result & Conclusion \\
\hline \multirow[t]{2}{*}{ Alkaloid } & $M C$ & - & Not detected \\
\hline & MEMC & - & Not detected \\
\hline \multirow[t]{2}{*}{ Saponin } & MC & $1+$ & Saponin was detected \\
\hline & MEMC & $1+$ & Saponin was detected \\
\hline \multirow[t]{2}{*}{ Flavonoid } & MC & $1+$ & Flavonoid was detected \\
\hline & MEMC & $1+$ & Flavonoid was detected \\
\hline \multirow[t]{2}{*}{ Tannins and polyphenolic compounds } & MC & $1+$ & Condensed tannins were detected \\
\hline & MEMC & $1+$ & Condensed tannins were detected \\
\hline \multirow[t]{2}{*}{ Triterpene } & $M C$ & $3+$ & Triterpene was detected \\
\hline & MEMC & $1+$ & Triterpene was detected \\
\hline \multirow[t]{2}{*}{ Steroid } & $M C$ & $3+$ & Steroid was detected \\
\hline & MEMC & $2+$ & Steroid was detected \\
\hline
\end{tabular}

For saponins: $+-1-2 \mathrm{~cm}$ froth; $++-2-3 \mathrm{~cm}$ froth; $+++->3 \mathrm{~cm}$ froth.

For flavonoids, tannins, triterpenes and steroids: + - weak colour; ++ - mild colour; +++ - strong colour.

For akalioids: +- negligible amount of precipitate; ++- weak precipitate; +++- strong precipitate. 


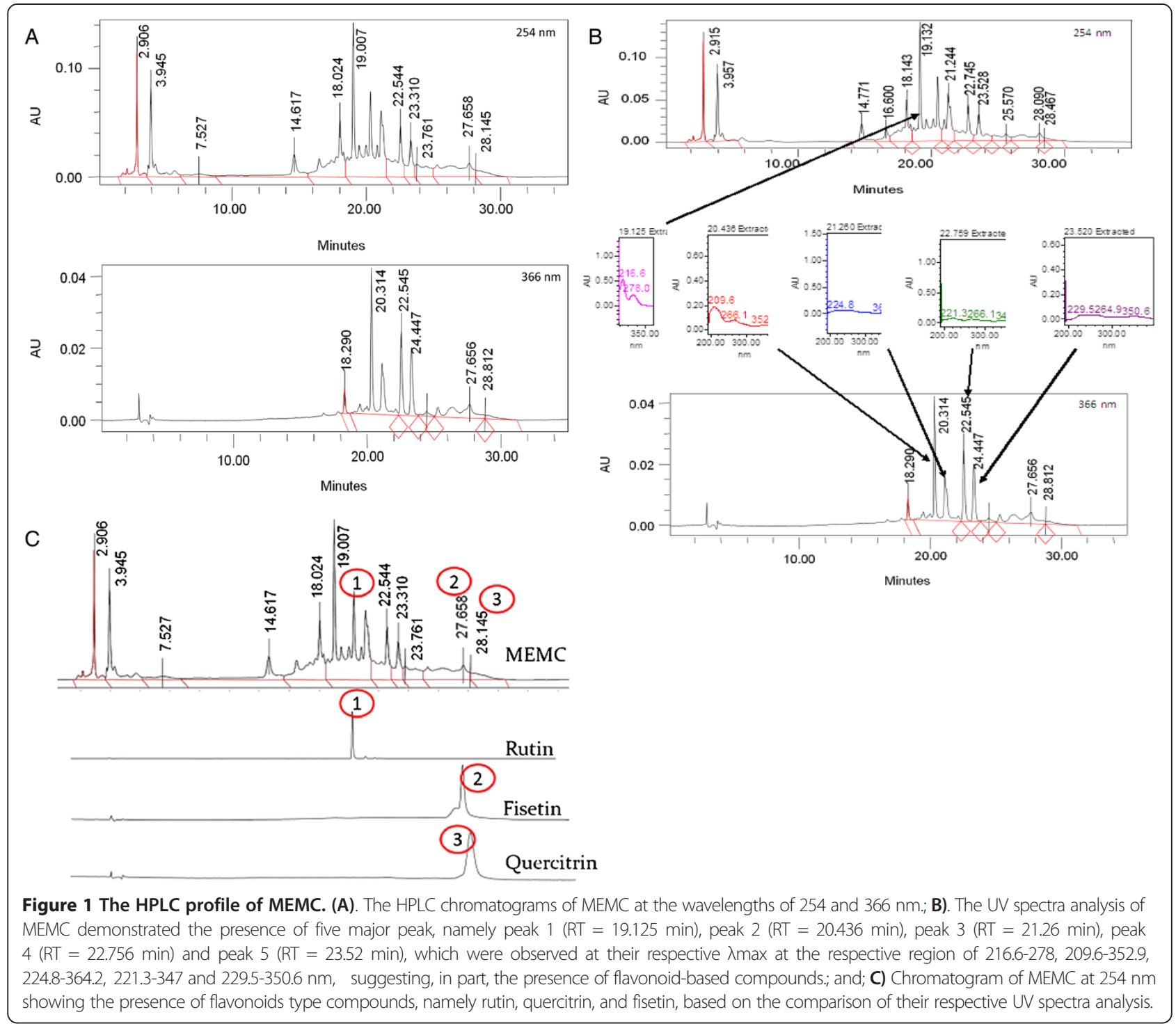

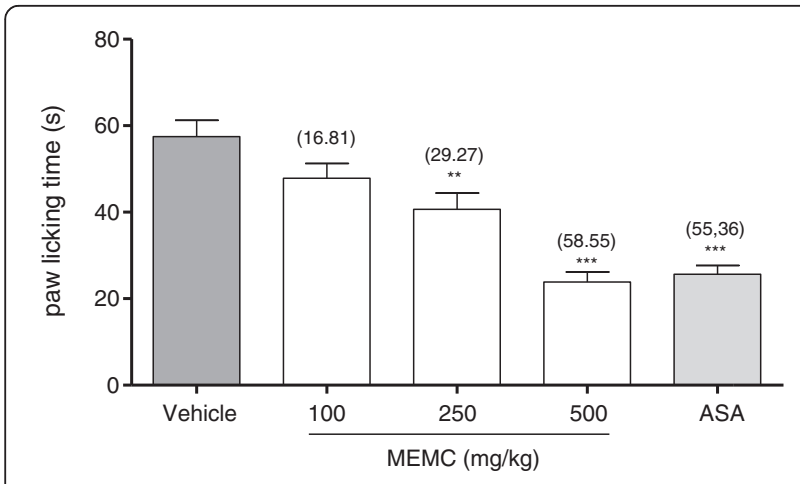

Figure 2 The antinociceptive activity of MEMC against PMA-induced paw licking. Each column represents the mean \pm S.E. M. of six rats. Control (C: $10 \%$ DMSO, p.o.), Phorbol-12 myristate-13 acetate (PMA; $0.05 \mu \mathrm{g} / 50 \mathrm{\mu L} / \mathrm{paw}), \mathrm{MEMC}(100,250$ and $500 \mathrm{mg} / \mathrm{kg}$, p.o.) and acetylsalicylic acid (ASA: $100 \mathrm{mg} / \mathrm{kg}$, p.o.). ${ }^{* *}, \mathrm{p}<0.01$ and ${ }^{* * *}, \mathrm{p}<0.001$ when compared to control group. administration of $3 \mathrm{mg} / \mathrm{kg}$ caffeine (Figure 5$), 10 \mathrm{mg} / \mathrm{kg}$ atropine (Figure 6), $0.15 \mathrm{mg} / \mathrm{kg}$ yohimbine (Figure 7), $0.2 \mathrm{mg} / \mathrm{kg}$ haloperidol (Figure 8), $0.2 \mathrm{mg} / \mathrm{kg}$ pindolol (Figure 9), or naltrindole, nor-binaltorphimine and $\beta$ funaltrexamine (Figure 10).

\section{Discussion}

Previous studies conducted in our laboratory demonstrates the ability of the MEMC to produce significant antinociceptive activity in both chemicals- and thermal-induced nociception test model indicating possible participation of central and peripheral antinociceptive mechanisms. The present study focuses further on the mechanisms of action involved in antinociception induced by crude methanol extract from the leaves of M. calabura. The results obtained revealed that the oral administration of MEMC produced significant dose-dependant inhibition of 


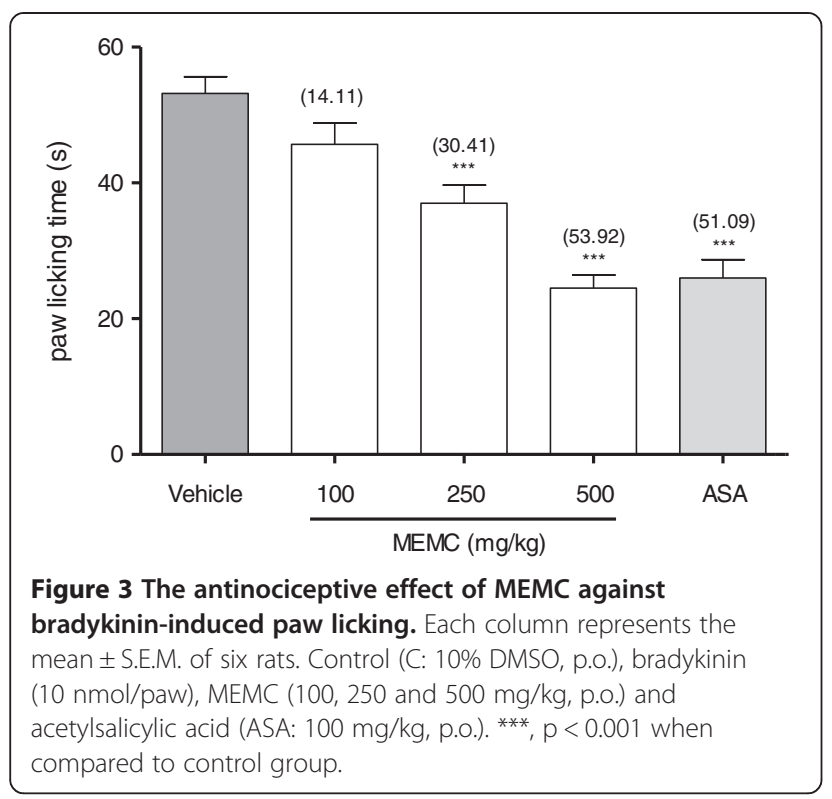

intraplantar (i.pl.) injection of bradykinin- and PMAinduced nociception.

Protein kinase $\mathrm{C}(\mathrm{PKC})$ has been reported to indirectly involved in the central sensitization of normally silent $\mathrm{N}$ methyl D-aspartate (NMDA) glutamate receptors located in the postsynaptic neuron [32,33], suggesting that the activation of PKC also play important role in the nociceptive transmission through a glutamatergic system. The i.pl. administration of PMA causes nociception, thermal hyperalgesia as well as mechanical allodynia in experimental animal model [34]. Based on the above statements, our data further strengthen the involvement of MEMC in central mechanism of antinociception as reported previously [23]. The activation of PKC occurs through interaction with intracellular lipid second messenger phosphatidylserine and diacylglycerol (DAG), and high level of calcium ions [35], which leads to the phosphorylation of many cellular components including the modulation of TRPV1 receptor [36-38]. Based on our findings, MEMC caused significant reduction in the nociceptive response induced by PMA in a dose-dependent manner, which in turn prevents the phosphorylation of TRPV1. This correlates well with our previous finding [23] where we demonstrated the possible involvement of TRPV1 in MEMC-induced antinociception through capsaicin-induced paw licking test. We, therefore, suggest that the MEMC antinociceptive activity involved partly the inhibition of TRPV1 receptor phosphorylation via attenuation of the PKC activation.

It is reported that PKC can also be directly activated by binding of bradykinin to its receptor [27]. This view was supported by our results demonstrating the MEMC's ability to suppress the nociception caused by bradykinin. Bradykinin is a potent inflammatory peptide messenger which is generated from a protein precursor, kallidin, through the action of specific enzyme kallikrein. During injury or inflammation, bradykinin will be released from the damaged tissues, from mast cells, as well as produced in the blood where it serves as vasodilators and increases vessel permeability [35]. This peptide is considered as one of the most potent pain-producing substance as it not only excites plenty of nociceptors, but also sensitizes them to other noxious stimuli through activation of B1 and B2 receptors $[35,39]$.

Bradykinin acted through G-coupled protein receptor, on dorsal root ganglion (DRG) sensory neurons, elicits marked increase in $\mathrm{Ca}^{2+}$, through activation of DAG and

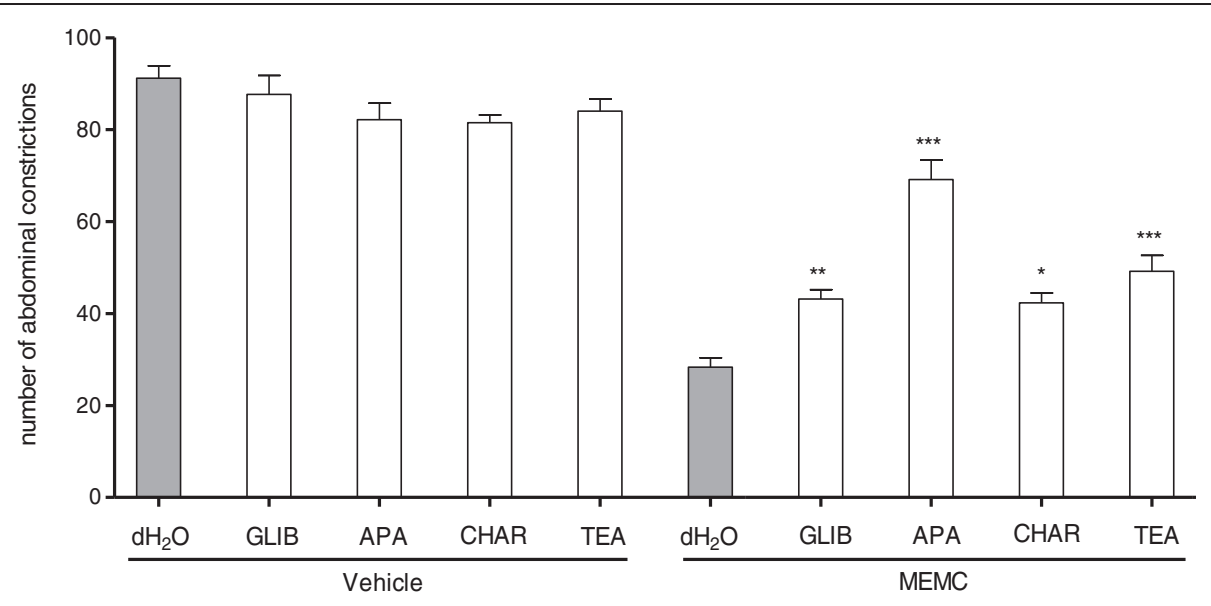

Figure 4 The effect of pre-treatment with glibenclamide, apamin, charybdotoxin and tetraethylammonium chloride in MEMC-induced antinociception against acetic acid-induced abdominal writhing test in mice. Each column represents the mean \pm S.E.M. of six mice. Vehicle (10\% DMSO, p.o.), MEMC (500 mg/kg, p.o.), glibenclamide (GLIB: 10 mg/kg, i.p.), apamin (APA: 0.04 mg/kg, i.p.), tetraethylammonium chloride (TEA: $0.01 \mathrm{mg} / \mathrm{kg}$, i.p.). ${ }^{* * *}, \mathrm{P}<0.001,{ }^{* *}, \mathrm{p}<0.01$ and ${ }^{*}, \mathrm{p}<0.05$ when compared to MEMC-treated group. 


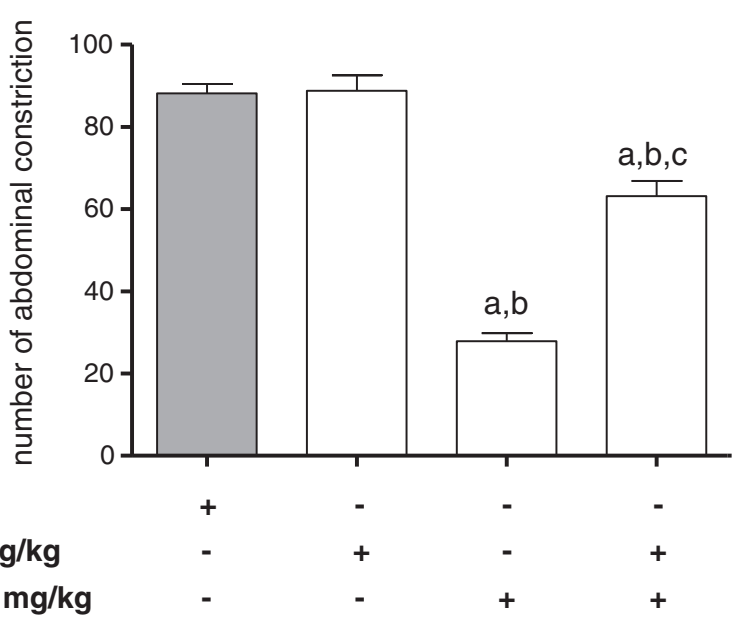

Figure 5 The involvement of the adenosinergic system in MEMC-induced antinociception against acetic acid-induced abdominal writhing test in mice. Each column represents the mean \pm S.E.M. of six mice. Control (C: $10 \%$ DMSO, p.o.), Caffeine (3 mg/kg, i.p.), and MEMC (500 mg/kg, p.o.). ${ }^{a} p<0.001$ significantly different from control group; ${ }^{b} p<0.001$ significantly different when compared caffeine-treated group; ${ }^{c} p<0.001$ when compared to MEMC-treated group.

PKC pathway $[40,41]$. Peripheral sensitization by bradykinin, which acted on the $\mathrm{A} \delta$ and C-fibers, evoke the release and synthesis of other second messengers, including prostaglandins, nitric oxide and neurokinins [40,42,43]. Pain induced through the introduction of bradykinin into the right hind paw of the experimental rat is significantly inhibited by oral administration of 250 and $500 \mathrm{mg} / \mathrm{kg}$ MEMC. It has been reported that the pain induced by bradykinin can be inhibited by cyclooxygenase (COX) inhibitor indomethacin [44], and therefore this type of pain is mediated by prostaglandins (probably $\mathrm{PGE}_{2}$ ). The ability of MEMC to inhibit bradykinin hyperalgesia correlates well with previous report [23], which proposed that MEMC antinociceptive activity seen in acetic acid-induced nociception may occurs through the inhibition of COX, as well as other mediators mentioned above or possibly by directly blocking the $\mathrm{B}_{2}$ receptors.

The noradrenergic receptor system involved greatly in descending modulation of pain pathways. Clonidine, a $\alpha_{2}$-adrenergic agonist, acting on the nerve endings of primary afferent fibers will inhibit the release of norepinephrine, glutamate and substance $\mathrm{P}$, as well as proinflammatory cytokines resulting in sedative and analgesic actions [45,46]. Our findings suggested the involvement of $\alpha_{2}$-adrenergic, but excluded the $\alpha_{1}$-adrenergic receptors since MEMC activity was significantly reversed, when challenged with yohimbine ( $\alpha_{2}$-adrenergic antagonist). In addition, serotonergic receptor pathway correlates with

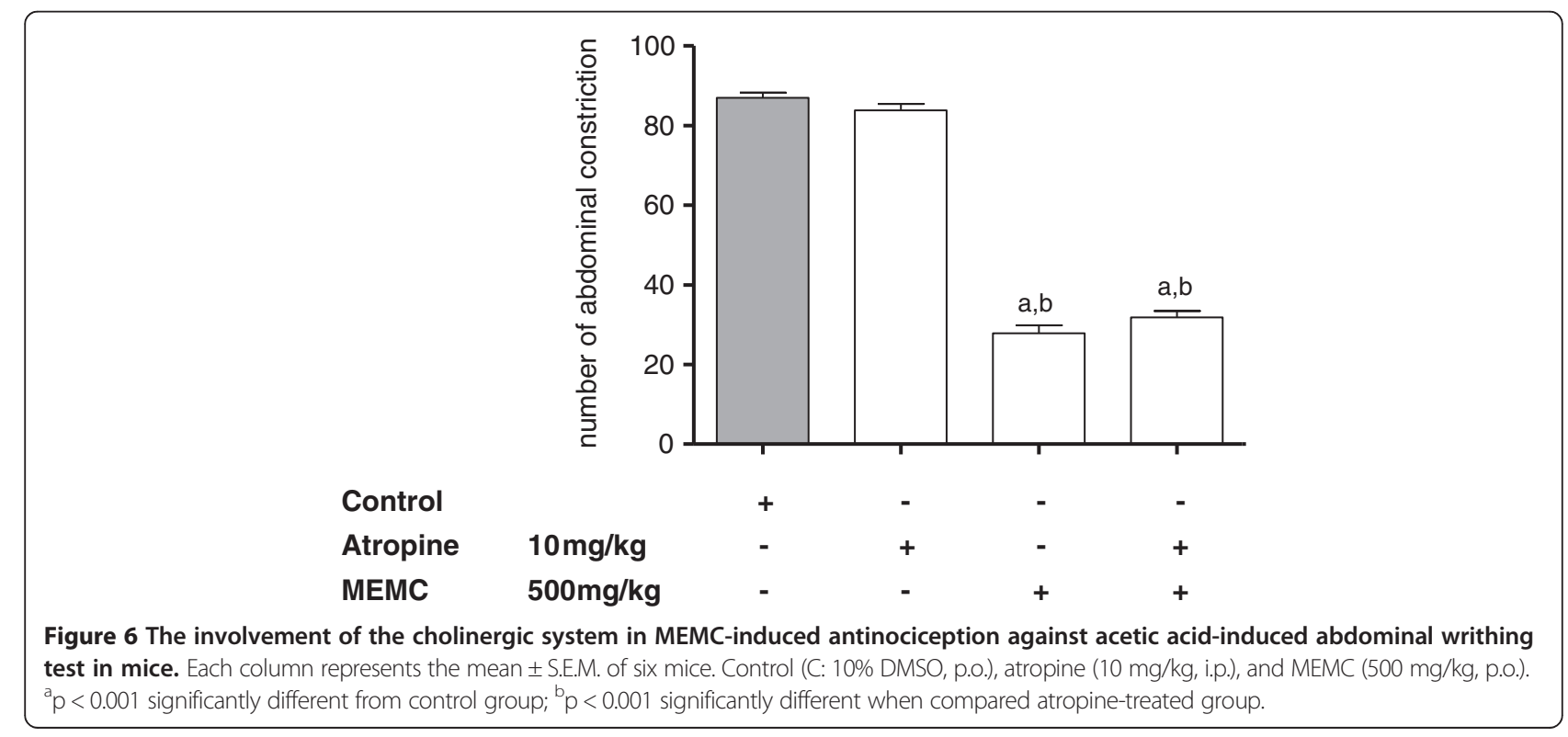




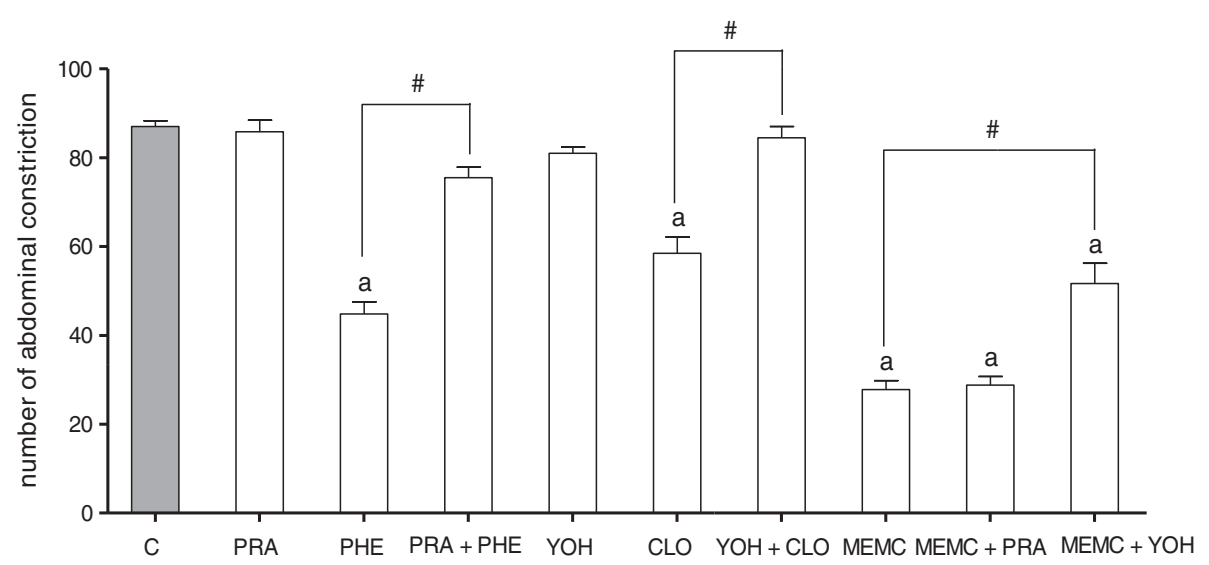

Figure 7 The involvement of the adrenergic system in MEMC-induced antinociception against acetic acid-induced abdominal writhing test in mice. Each column represents the mean \pm S.E.M. of six mice. Control (C: 10\% DMSO, p.o.), prazosin (PRA: 0.15 mg/kg, i.p.), Phenylphrine (PHE: $10 \mathrm{mg} / \mathrm{kg}$, i.p.), Yohimbine (YOH: $0.15 \mathrm{mg} / \mathrm{kg}$, i.p.), Clonidine (CLO: $0.15 \mathrm{mg} / \mathrm{kg}$, i.p.) and MEMC (500 mg/kg, p.o.). ${ }^{\mathrm{a}} \mathrm{p}<0.05$ significantly different from control group; ${ }^{\#} p<0.05$ significantly different when compared between respected treatment groups.

that of noradrenergic system. Activation of serotonergic receptor will cause the release of noradrenaline which activate postsynaptic $\alpha_{2}$-adrenergic in the spinal cord leading to antinociception $[47,48]$, and pretreatment with pindolol (5- $\mathrm{HT}_{1 \mathrm{~A} / 1 \mathrm{~B}}$ receptor/ $\beta$-adrenoceptor inhibitor) significantly reversed MEMC antinociceptive activity indicating its role in serotonergic system.

We also demonstrated the involvement of adenosinergic receptor system in MEMC-induced antinociception. Caffeine, a non-selective adenosinergic receptor antagonist significantly reduced the action of MEMC. Pharmacologically, caffeine blocked adenosine $A_{1}, A_{2 A}, A_{2 B}$, and $A_{3}$ receptor but with lower affinity $[49,50]$. Adenosine receptor activation particularly $\mathrm{A}_{1}$ produces antinociception, by reducing $\mathrm{PGE}_{2}[51,52]$ and triggers $\mathrm{NO} / \mathrm{cGMP} / \mathrm{PKG} / \mathrm{K}_{\mathrm{ATP}}$ pathway [53] in acute pain, and increases pain threshold [54] as well as inhibit glutamate release [55] in chronic pain. Adenosinergic and serotonergic systems are closely involved as $\mathrm{A}_{1}$ receptor antagonist can block serotonin analgesic action [56]. On the other hand, atropine (a cholinergic receptor antagonist) and haloperidol (a dopaminergic receptor antagonist) did not cause any significant changes in the number of abdominal constrictions, indicating lack of involvement of those receptor systems in MEMC antinociception.

The activation of $5-\mathrm{HT}_{1 \mathrm{~A}}$ has been shown to promote the opening of $\mathrm{K}^{+}$channels and closing of $\mathrm{Ca}^{+}$channels through coupling negatively to adenylyl cyclase which lead

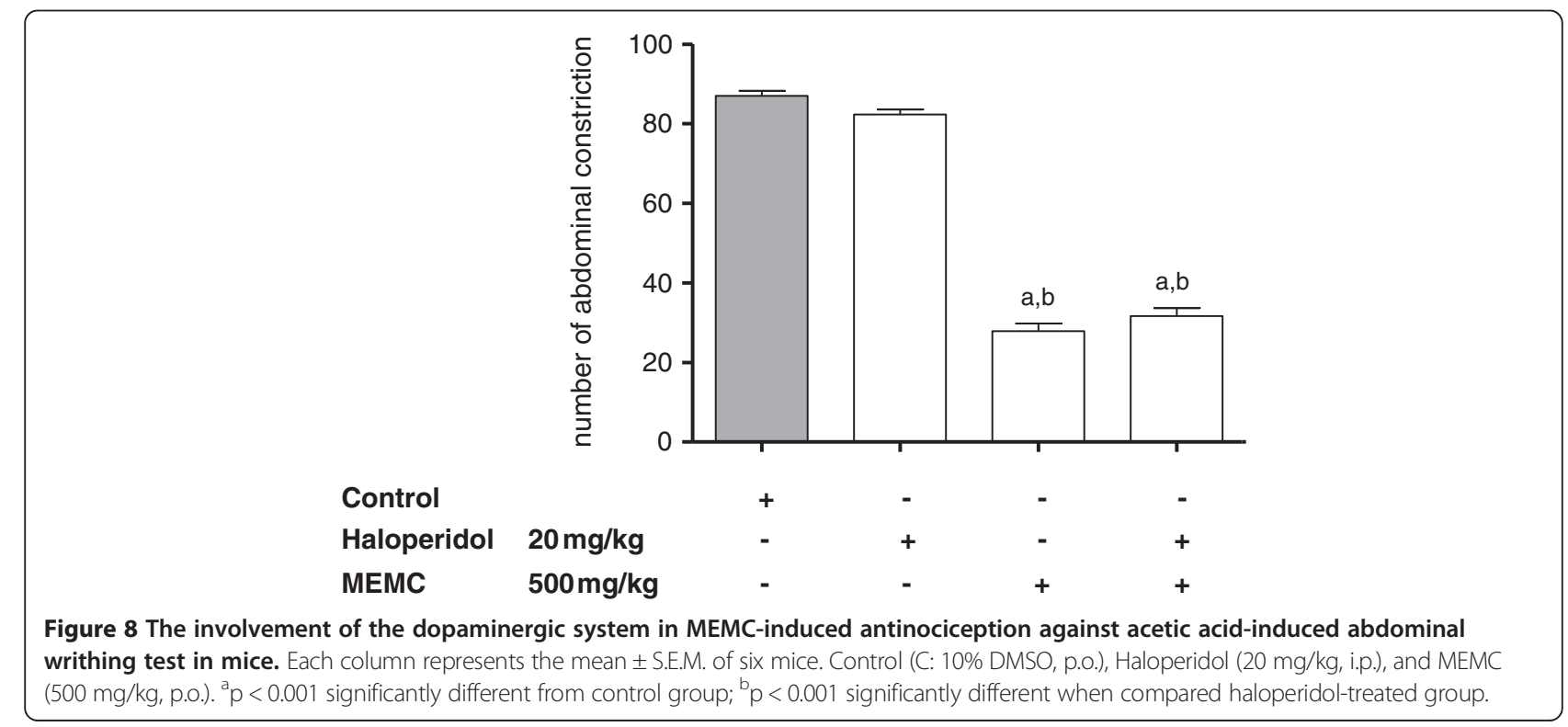




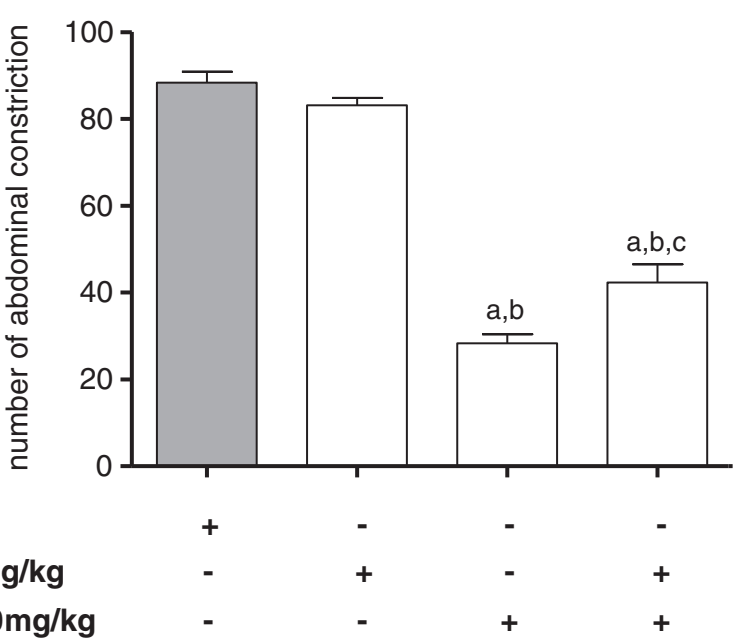

Figure 9 The involvement of the serotonergic system in MEMC-induced antinociception against acetic acid-induced abdominal writhing test in mice. Each column represents the mean \pm S.E.M. of six mice. Control (C: $10 \%$ DMSO, p.o.), Pindolol (1 mg/kg, i.p.), and MEMC (500 mg/kg, p.o.). ${ }^{a} p<0.001$ significantly different from control group; ${ }^{b} p<0.001$ significantly different when compared pindolol-treated group; ${ }^{c} p<0.01$ when compared to MEMC-treated group.

to sensory transmission inhibition [57]. Corroborating to the finding, we demonstrated that pre-treatment with glibenclamide (a specific ATP-sensitive $\mathrm{K}^{+}$channel blocker), apamin (small conductance $\mathrm{Ca}^{2+}$-activated $\mathrm{K}^{+}$channels), charybdotoxin (an inhibitor of large conductance $\mathrm{Ca}^{2+}$-activated $\mathrm{K}^{+}$channels) and tetraethylammonium chloride (a non-selective voltage dependant $\mathrm{K}^{+}$channel inhibitor) significantly reversed the antinociceptive effect of MEMC. The opening of ATP-sensitive $\mathrm{K}^{+}$channel has been reported to participate in opioid-mediated antinociception, at the level of $\mathrm{K}^{+}$and not opioid receptor [58], since specific ATP-sensitive $\mathrm{K}^{+}$channel blockers (glibenclamide and gliquidone) shown to dose-dependently reduce the antinociceptive of morphine $[59,60]$. This correlates well with previous study demonstrating the involvement of MEMC in opioid receptor system [23].

Previously, we have demonstrated the involvement of opioid receptor in MEMC antinociception using nonselective opioid antagonist, naloxone [23]. In the present study, we elucidated the possible role of opioid receptor subtype in the modulation of MEMC antinociception using $\mu, \delta$, and $\kappa$ opioid antagonists. Our findings demonstrated MEMC activity was significantly attenuated by all of the opioid subtypes' antagonists, suggesting the role of those receptors in the analgesic activity of MEMC. These receptors, found throughout the nervous system, spinal cord, midbrain and cortex, can mediate pain inhibition [61], and the report showed increased expression of $\delta$ opioid receptor

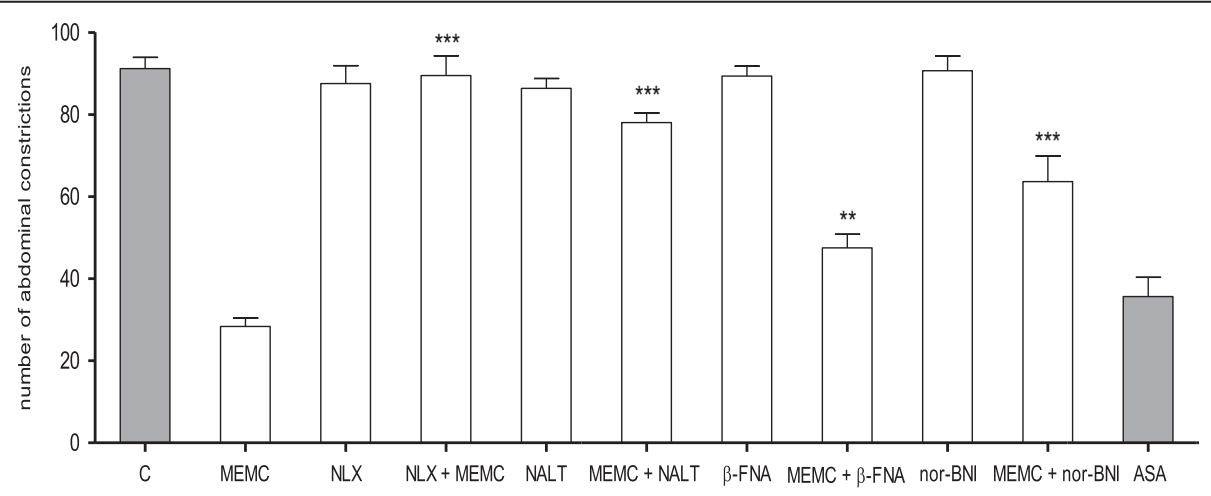

Figure 10 Analysis of opioid receptor subtypes involvement in MEMC-induced antinociception against acetic acid-induced writhing test inn mice. Control (C: 10\% DMSO, p.o.), MEMC (500 mg/kg, p.o.), naloxone (NLX: 5 mg/kg, i.p.), naltrindole (NALT: 1 mg/kg, i.p.), $\beta$-funaltrexamine ( $\beta-F N A: 10$ mg/kg, i.p.), nor-binaltorphimine (nor-BNl: 1 mg/kg, i.p.) and acetylsalicylic acid (ASA: $100 \mathrm{mg} / \mathrm{kg}$, p.o.). ${ }^{* * *} \mathrm{P}<0.001$ when compared to the group treated only with MEMC; $\mathrm{p}<0.01$ when compared to the group treated only with MEMC. 
when $\mu$ receptors were repeatedly activated [62], which accounted for the synergistic action seen in other studies $[63,64]$.

The phytochemical screening shows the presence of flavonoids, triterpenes, saponins steroids and tannins which is in line with previous report [15], and interestingly all of these bioactive constituents has been reported to be involved in antinociceptive activity [65-68]. Our HPLC analysis revealed the possible presence of flavonols, namely rutin, quercitrin and fisetin. The ability of quercitrin to inhibit the pro-inflammatory mediators involved in pain modulation, especially cytokines, has been reported [69]. Rutin has been reported to produced antinociceptive activity by inhibiting both COX and lipooxygenase (LOX) pathways at high concentration [70]. Various reports have demonstrated that these types of flavonoids possess significant antinociceptive and/or anti-inflammatory activities [71-73].

\section{Conclusions}

We conclude that the antinociceptive activity of MEMC may also be mediated through inhibition of PKC pathway and bradykinin receptor as well as through the activation of $\mathrm{K}^{+}$channels, adrenergic, serotonergic and adenosinergic receptor systems. Our findings also revealed the possible interaction of MEMC with the three opioid receptor subtypes. The activity seen could be due to the synergistic effect of flavonoids, saponins, tannins and steroids.

\section{Competing interest}

The authors declare that there is no competing interest.

\section{Authors' contribution}

MHMS carried out the experiments and drafted the manuscript. MSC, AAK, TLK and MZS participated in its design, involved in the statistical analysis and helped to draft the manuscript. ZAZ conceived of the study, participated in its design and helped to draft the manuscript. All authors read and approved the final manuscript.

\section{Acknowledgements}

This study was supported by the Science Fund Research Grant (Reference no. 06-01-04-SF1127) awarded by the Ministry of Science Technology and Innovation (MOSTI), Malaysia and the Research University Grant Scheme (Reference no. 04-02-12-2019RU) from the Universiti Putra Malaysia, Malaysia. The authors thanked the Faculty of Medicine and Health Sciences, Universiti Putra Malaysia, Malaysia for providing the facilities to carry out this study.

\section{Author details}

${ }^{1}$ Department of Biomedical Sciences, Faculty of Medicine and Health Sciences, Universiti Putra Malaysia, 43400 Serdang, Selangor, Malaysia. ${ }^{2}$ Department of Veterinary Preclinical Sciences, Faculty of Veterinary Medicine, Universiti Putra Malaysia, 43400 Serdang, Selangor, Malaysia. ${ }^{3}$ Integrative Pharmacogenomics Institute (iPROMISE), Level 7, FF3, Universiti Teknologi MARA, Puncak Alam Campus, 42300 Puncak Alam, Selangor, Malaysia.

Received: 17 October 2013 Accepted: 11 February 2014 Published: 20 February 2014

\section{References}

1. Raj PP: Pain Medicine: A Comprehensive Review. 2nd edition. Texas: Mosby Inc; 2003.
2. Strong J, Unruh AM, Wright A, Baxter GD, Wall PD: Pain: a textbook for therapists. London: Churchill Livingstone; 2002.

3. Hawthorn J, Redmond K: Pain: causes and management. Oxford: Blackwell Science Ltd; 1998.

4. Paris PM, Stewart RD: Pain management in emergency medicine. Connecticut: Appleton and Lange; 1988.

5. Katzung BG: Basic and Clinical Pharmacology. 9th edition; 2004. International Edition.

6. Holt GA, Chandra A: Herbs in the modern healthcare environment-an overview of uses, legalities and the role of the healthcare professional. Clin Res Regul Aff (USA) 2002, 19:83-107.

7. Rates SMK: Plants as source of drugs. Toxicon 2001, 29:603.

8. Kaneda N, Pezzuto JM, Soejarto DD, Kinghorn AD, Farnsworth NR, Santisuk T, Tuchinda P, Udchachon J, Reutrakul V: Plant anticancer agents, XLVIII. New cytotoxic flavonoids from Muntingia calabura roots. J Nat Prod 1991, 54:196-206.

9. Nshimo CM, Pezzuto JM, Kinghorn AD, Farnsworth NR: Cytotoxic constituents of Muntingia calabura leaves and stems collected in Thailand. Int J Pharmacogn 1993, 31:77-81.

10. Perez-Arbelaez E: In Plantas Medicinales y Venenosas de Colombia. Edited by Salazar H. Colombia: Medellin; 1975:192.

11. Su BN, Jung Park E, Vigo JS, Graham JG, Cabieses F, Fong HH, Pezzuto JM, Kinghorn AD: Activity-guided isolation of the chemical constituents of Muntingia calabura using a quinone reductase induction assay. Phytochemistry 2003, 63:335-341.

12. Zakaria ZA, Fatimah CA, Mat Jais AM, Zaiton H, Henie EFP, Sulaiman MR, Somchit MN, Thenamuha M, Kasthuri D: The in vitro antibacterial activity of Muntingia calabura extracts. Int J Pharmacol 2006, 2:439-442.

13. Zakaria ZA, Sufian AS, Ramasamy K, Ahmat N, Sulaiman MR, Arifah AK, Zuraini A, Somchit MN: In vitro antimicrobial activity of Muntigia calabura extracts and fractions. Afr J Microbiol Res 2010, 4:304-308.

14. Zakaria ZA, Mohd Nor Hazalin NA, Mohd Zaid SNH, Abdul Ghani M, Hassan $\mathrm{MH}$, Gopalan HK, Sulaiman MR: Antinociceptive, anti-inflammatory and antipyretic effects of Muntingia calabura aqueous extract in animal models. J Nat Med 2007, 61:443-448.

15. Zakaria ZA, Kumar GH, Mohd Zaid SNH, Abdul Ghani M, Hassan MH, Mohd Nor Hazalin NA, Khamis MM, Devi RG: Analgesic and antipyretic actions of Muntingia calabura leaves chloroform extract in animal models. Orient Pharm Exp Med 2007, 7:34-40.

16. Zakaria ZA, Mohammad AM, Mohd Jamil NS, Rofiee MS, Hussain MK, Sulaiman MR, Teh LK, Salleh MZ: In vitro antiproliferative and antioxidant activities of the extracts of Muntingia calabura leaves. Am J Chin Med 2011, 39:183-200

17. Shih $C D$, Chen JJ, Lee $H H$ : Activation of nitric oxide signaling pathway mediates hypotensive effect of Muntingia calabura L. (Tiliaceae) leaf extract. Am J Chin Med 2006, 34:857-872.

18. Balan T, Mohd Sani MH, Suppaiah V, Mohtarrudin N, Suhaili Z, Ahmad Z, Zakaria ZA: Antiulcer activity of Muntingia calabura leaves involves the modulation of endogenous nitric oxide and nonprotein sulfhydryl compounds. Pharm Biol 2013. doi:10.3109/13880209.2013.839713.

19. Zakaria ZA, Sulaiman MR, Jais AM, Somchit MN, Jayaraman KV, Balakhrisnan G, Abdullah FC: The antinociceptive activity of Muntingia calabura aqueous extract and the involvement of L-arginine/nitric oxide/cyclic guanosine monophosphate pathway in its observed activity in mice. Fundam Clin Pharmacol 2006, 20:365-372.

20. Zakaria ZA, Mustapha S, Sulaiman MR, Mat Jais AM, Somchit MN, Abdullah FC: The antinociceptive action of aqueous extract from Muntingia calabura leaves: The role of opioid receptors. Med Prin Pract 2007c, 16:130-136.

21. Zakaria ZA, Hassan MH, Nurul Aqmar MN, Abd Ghani M, Mohd Zaid SN, Sulaiman MR, Hanan Kumar G, Fatimah CA: Effects of various nonopioid receptor antagonist on the antinociceptive activity of Muntingia calabura extracts in mice. Methods Find Exp Clin Pharmacol 2007, 29: 515-520.

22. Zakaria ZA, Somchit MN, Sulaiman MR, Mat Jais AM, Fatimah CA: Effects of various receptor antagonists, $\mathrm{pH}$ and enzymes on Muntingia calabura antinociception in mice. Res J Pharmacol 2008, 2:31-37.

23. Mohd Sani MH, Zakaria ZA, Balan T, Teh LK, Salleh MZ: Antinociceptive Activity of Methanol Extract of Muntingia calabura Leaves and the Mechanisms of Action Involved. Evid Based Compl Alt 2012: doi:10.1155/ 2012/890361. 
24. Mohamad Yusof MI, Salleh MZ, Lay Kek T, Ahmat N, Nik Azmin NF, Zakaria ZA: Activity-Guided Isolation of Bioactive Constituents with Antinociceptive Activity from Muntingia calabura L. Leaves Using the Formalin Test. Evid Based Compl Alt 2013. doi:10.1155/2013/715074.

25. Zimmermann M: Ethical guidelines for investigations of experimental pain in conscious animals. Pain 1983, 16:109-110.

26. Savegnago L, Pinto LG, Jesse CR, Alves D, Rocha JB, Nogueira CW, Zeni G: Antinociceptive properties of diphenyl diselenide: evidences for the mechanism of action. Eur J Pharmacol 2007, 555:129-138.

27. Ferreira J, da Silva GL, Calixto JB: Contribution of vanilloid receptors to the overt nociception induced by B2 kinin receptor activation in mice. Brit $J$ Pharmacol 2004, 141:787-794.

28. Alves D, Duarte I: Involvement of ATP-sensitive $\mathrm{K}(+)$ channels in the peripheral antinociceptive effect induced by dipyrone. Eur J Pharmacol 2002, 444:47-52.

29. De Souza MM, Pereira MA, Ardenghi JV, Mora TC, Bresciani LF, Yunes RA, Delle Monache F, Cechinel-Filho V: Filicene obtained from Adiantum cuneatum interacts with the cholinergic, dopaminergic, glutamatergic, GABAergic and tachykinergic systems to exert antinociceptive effect in mice. Pharmacol Biochem Behav 2009, 93:40-46.

30. Choi SS, Han KJ, Lee HK, Han EJ, Suh HW: Possible antinociceptive mechanisms of opioid receptor antagonists in the mouse formalin test. Pharmacol Biochem Behav 2003, 75:121-124.

31. Reeta K, Mediratta PK, Rathi N, Jain H, Chugh C, Sharma KK: Role of kappa and delta opioid receptors in the antinociceptive effect of oxytocin in formalin-induced pain response in mice. Regul Pept 2006, 135:85-90.

32. Basbaum Al, Bushnell MC: Science of Pain. San Diego: Elsevier Inc.; 2009

33. Ji RR, Woolf $C$ J: Neuronal plasticity and signal transduction in nociceptive neurons: implications for the initiation and maintenance of pathological pain. Neurobiol Dis 2001, 8:1-10.

34. Khalid MH, Akhtar MN, Mohamad AS, Perimal EK, Akira A, Israf DA, Lajis N, Sulaiman MR: Antinociceptive effect of the essential oil of Zingiber zerumbet in mice: possible mechanisms. J Ethnopharmacol 2011, 137:345-351.

35. Schmidt RF, Willis WD: Encyclopedia of pain, Volume 1. New York: Springer-verlag Berlin Heilberg; 2007.

36. Chuang HH, Prescott ED, Kong H, Shields S, Jordt SE, Basbaum Al, Chao MV, Julius D: Bradykinin and nerve growth factor release the capsaicin receptor from Ptdlns(4,5)P2-mediated inhibition. Nature 2001, 411: 957-962.

37. Ferreira J, Triches KM, Medeiros R, Calixto JB: Mechanisms involved in the nociception produced by peripheral protein kinase $C$ activation in mice. Pain 2005, 117:171-181.

38. Vellani V, Mapplebeck S, Moriondo A, Davis JB, McNaughton PA: Protein kinase $C$ activation potentiates gating of the vanilloid receptor VR1 by capsaicin, protons, heat and anandamide. J Physiol Lond 2001, 543:813-825.

39. Riley J, Boulis NM: Molecular mechanisms of pain: a basis for chronic pain and therapeutic approaches based on the cell and the gene. Clin Neurosci 2006, 53:77-97.

40. Mayer S, Izydorczyk I, Reeh PW, Grubb BD: Bradykinin-induced nociceptor sensitisation to heat depends on cox-1 and cox-2 in isolated rat skin. Pain 2007, 130:14-24.

41. Smith JA, Davis CL, Burgess GM: Prostaglandin E2-induced sensitization of bradykinin-evoked responses in rat dorsal root ganglion neurons is mediated by cAMP-dependent protein kinase A. Eur J Neurosci 2000 12:3250-3258

42. Calixto JB, Cabrini DA, Ferreira J, Campos MM: Kinins in pain and inflammation. Pain 2000, 87:1-5.

43. Sauer SK, Schafer D, Kress M, Reeh PW: Stimulated prostaglandin E2 release from rat skin, in vitro. Life Sci 1998, 62:2045-2055.

44. Janig W: Autonomic nervous system and pain. In Science of Pain, Volume 1. Edited by Basbaum Al, Bushnell MC. San Diego: Elsevier Inc; 2009.

45. Bantel C, Maze M, Stone L, Wilcox G: Alpha 2-adrenergic agonists in pain treatment. In Encyclopedia of pain. 1st edition. Edited by Schmidt RF, Willis WD. New York: Springer-verlag Berlin Heilberg; 2007.

46. Lavand'homme PM, Eisenach JC: Perioperative administration of the alpha2-adrenoceptor agonist clonidine at the site of nerve injury reduces the development of mechanical hypersensitivity and modulates local cytokine expression. Pain 2003, 105:247-254.
47. Carrol I, Mackey S, Gaeta R: The role of adrenergic receptors and pain: the good, the bad, and the unknown. Semin Anesth Perio M 2007, 26:17-21.

48. Sawynok J, Reid A: Interactions of descending serotonergic systems with other neurotransmitters in the modulation of nociception. Behav Brain Res 1996, 73:63-68.

49. Fredholm BB, Battig K, Holmen J, Nehlig A, Avartau EE: Actions of caffeine in the brain with special reference to factors that contribute to its widespread use. Pharmacol Rev 1999, 51:83-133.

50. Sawynok J: Caffeine and pain. Pain 2011, 152:726-729.

51. Karlsten R, Gordh T, Post C: Local antinociceptive and hyperalgesic effects in the formalin test after peripheral administration of adenosine analogues in mice. Pharmacol Toxicol 1992, 70:434-438.

52. Taiwo YO, Levine JD: Direct cutaneous hyperalgesia induced by adenosine. Neurosci 1990, 38:757-762

53. Lima FO, Souza GR, Verri WA Jr, Parada CA, Ferreira SH, Cunha FQ, Cunha TM: Direct blockade of inflammatory hypernociception by peripheral $A$ adenosine receptors: involvement of the NO/CGMP/PKG/K $\mathrm{K}_{\text {ATP }}$ signaling pathway. Pain 2010, 151:506-515.

54. Wu WP, Hao JX, Halldner L, Lövdahl C, DeLander GE, Wiesenfeld-Hallin Z, Fredholm BB, Xu XJ: Increased nociceptive response in mice lacking the adenosine A1 receptor. Pain 2005, 113:395-404

55. Nascimento FP, Macedo SJ Jr, Santos ARS: The involvement of purinergic system in pain: adenosine receptors and inosine as pharmacological tools in future treatments. In Pharmacology. Edited by Luca G. InTech; 2012. doi:10.5772/33754

56. Sawynok J: Adenosine receptor activation and nociception. Eur J Pharmacol 1998, 347:1-11.

57. Ito A, Kumamoto E, Takeda M, Shibata K, Sagai H, Yoshimura M: Mechanisms for ovariectomy-induced hyperalgesia and its relief by calcitonin: participation of 5-HT1A-like receptor on C-afferent terminals in substantia gelatinosa of the rat spinal cord. J Neurosci 2000, 20:6302-6308.

58. Raffa RB, Codd EE: Lack of glibenclamide or TEA affinity for opioid receptors: further evidence for in vivo modulation of antinociception at K + channels. Brain Res 1994, 650:146-148.

59. Ocana M, Del Pozo E, Barrios M, Robles LI, Baeyens JM: An ATP-dependent potassium channel blocker antagonizes morphine analgesia. Eur J Pharmacol 1990, 186:377-378.

60. Rodrigues AR, Duarte ID: The peripheral antinociceptive effect induced by morphine is associated with ATP-sensitive $\mathrm{K}+$ channels. Brit J Pharmacol 2000, 129:110-114.

61. Rittner HL, Machelska H, Stein C: Immune System, Pain and Analgesia. In Science of Pain, Volume 1. 1st edition. Edited by Basbaum Al, Bushnell MC. San Diego: Elsevier Inc; 2009.

62. Cahill CM, Morinville A, Lee MC, Vincent JP, Collier B, Beaudet A: Prolonged morphine treatment targets delta opioid receptors to neuronal plasma membranes and enhances \{delta\}-mediated antinociception. J Neurosci 2001, 21:7598.

63. Hurley RW, Hammond DL: Contribution of endogenous enkephalins to the enhanced analgesic effects of supraspinal micro opioid receptor agonists after inflammatory injury. J Neurosci 2001, 21:2536.

64. Schidmt BL, Tambeli CH, Levine JD, Gear RW: mu/cooperativity and opposing opioid effects in nucleus accumbens mediated antinociception in the rat. Eur J Neurosci 2002, 15:861-868.

65. Beirith A, Santos ARS, Calixto JB, Hess SC, Messana I, Ferrari F, Yunes RA: Study of the antinociceptive action of the ethanolic extract and the triterpene 24-hydroxytormentic acid isolated from the stem bark of Ocotea suaveolens. Planta Med 1999, 65:50-55.

66. Karumi Y, Onyeyili P, Ogugbuaja VO: Anti-inflammatory and antinociceptive (analgesic) properties of Momordical balsamina Linn. (Balsam apple) leaves in rats. Pak J Biol Sci 2003, 6:1515-1518.

67. Musa AM, Aliyu AB, Yaro AH, Magaji MG, Hassan HS, Abdullahi MI: Preliminary phytochemical, analgesic and anti-inflammatory studies of the methanol extract of Anisopus mannii in rodents. Afr J Pharm Pharmacol 2009, 3:374-378.

68. Starec M, Waitzov'a D, Elis J: Evaluation of the analgesic effect of RG-tannin using the "hot plate" and "tail flick" method in mice (in Czech). Cesk Farm 1988, 37:319-321.

69. Comalada M, Camuesco D, Sierra S, Ballester I, Xaus J, Gálvez J, Zarzuelo A: In vivo quercitrin anti-inflammatory effect involves release of quercetin which inhibits inflammation through down-regulation of the NF-kappaB pathway. Eur J Immunol 2005, 35:584-592 
70. Chua LS: A review on plant-based rutin extraction methods and its pharmacological activities. J Ethnopharmacol 2013, 150:805-817.

71. Calixto JB, Beirith A, Ferreira J, Santos AR, Cechinel Filho V, Yunes RA: Naturally occurring antinociceptive substances from plants. Phytother Res 2000, 14:401-418.

72. Bittar M, de Souza MM, Yunes RA, Lento R, Delle Monache F, Cechinel Filho V: Antinociceptive activity of $|3| l$,8 -binaringenin, a biflavonoid present in plants of the guttiferae. Planta Med 2000, 66:84-86.

73. Gadotti VM, Santos ARS, Meyre-Silva C, Schmeling LO, Machado C, Liz FH, Filho VC: Antinociceptive action of the extract and the flavonoid quercitrin isolated from Bauhinia microstachya leaves. J Pharm Pharmacol 2005, 57:1345-1351.

doi:10.1186/1472-6882-14-63

Cite this article as: Zakaria et al:: Antinociceptive activity of methanolic extract of Muntingia calabura leaves: further elucidation of the possible mechanisms. BMC Complementary and Alternative Medicine 2014 14:63.

\section{Submit your next manuscript to BioMed Central and take full advantage of:}

- Convenient online submission

- Thorough peer review

- No space constraints or color figure charges

- Immediate publication on acceptance

- Inclusion in PubMed, CAS, Scopus and Google Scholar

- Research which is freely available for redistribution 